\title{
ADR Accounting Principles Choice And The Market Reaction To Form 20-F
}

\author{
David L. Senteney, Ohio University, USA \\ Grace H. Gao, West Virginia University, USA \\ Mohammad S. Bazaz, California State University, USA
}

\begin{abstract}
In this study, we conjecture that non-U.S. firms, choosing to be listed on the major U.S. exchanges, will incur the added costs associated with the supplemental disclosure requirements in order to get that information impounded in the home country equity share price via the ADR share price in the manner described by Fishman and Hagerty (1989). More specifically, we evaluate the equity share response to U.S.-listed ADR Form 20-F filing in a manner similar to Chen and Sami (2009, 2008) anticipating that the incremental disclosures will prompt ADR and equity security share responses. Unlike prior studies, we investigate whether the Form 20-F filings prompt U.S. dominant cross-market information flows from the ADR share market back to the home country equity share market proportional to the incremental Form 20-F information. We employ bivariate and single equation models of the cross-market ADR and equity security share response to the filing, controlling for the firm-specific Form 20-F accounting principles choice. Preliminary results indicate that both ADR and equity security share markets respond to the Form 20-F filing. There is a strong indication that the U.S. ADR share market response dominates the cross-market information flow driving the home country equity share market response. Furthermore, we find that the cross-market response to ADR Form 20-F filing is not equal across the three available accounting principle choices in either the ADR share market or the home country equity share market. Our results are consistent with U.S. GAAP conveying the most of new price relevant information, IFRS, and local accounting standards being informative but not to the same extent.
\end{abstract}

Keywords: Accounting Principle Choice; ADR; Form 20-F

\section{INTRODUCTION}

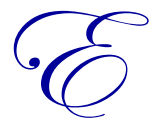

xtant empirical research indicates that, in numerous instances, significant information flows from the U.S. stock exchanges to the home country equity share exchanges. This suggests that U.S. stock exchanges play a preeminent role in the cross-market transmission of equity share price relevant information. King and Wadhwani (1990), Bae and Karolyi (1994), Kanas (1998), and Ng (2000) examine the relation among larger and emerging market returns. They conclude that the U.S. markets are dominant for returns in the sense that information flows from the U.S. market to other global markets. Naturally, a direct consequence of the increased interrelation of global equity markets is that the firm-specific disclosures arising in one market may prompt security return and trading volume responses in another.

The purpose of this study is to examine comparative aspects of the Form 20-F filing date cross-market $\mathrm{ADR}$ and equity return and trading volume reaction wherein substantial cross-market pricing differentials are quickly arbitraged away by rent seeking investors and, as a result, afford an opportunity to empirically observe the cross-market transfer of information. The perceived higher quality accounting disclosures required by the SEC for Level II and III ADRs listed on the major U.S. exchanges ought to prompt an equity share market response proportional to the new information and, consequently, a rapid erosion of any accompanying pricing differentials. One contribution of this study is a more focused study of cross-market information transfers by examining the ADR equity security return and trading volume behavior surrounding the filing date of Form 20-F. Furthermore, in contrast with prior studies, this research provides a more complete perspective of the ADR and equity market 
reaction to the Form 20-F filing for ADRs as well as the role of security returns and trading volume in cross-market information transfers analogous to Chen and Sami (2008) and Chen and Sami (2009).

The results of this study indicate that investors in both ADR and equity share markets respond to the disclosures provided in Form 20-F. In addition, this study documents significant cross-market information transfers following Form 20-F U.S.-GAAP disclosures via associations between U.S.-listed ADR unexpected returns and unexpected trading volume and the equity security market reaction to the ADR Form 20-F filing in the home country market. In particular, we find that cross-market information transfers are the strongest for non-U.S. firms filing the SEC Form 20-F using U.S. GAAP or home country GAAP with reconciliation to U.S. GAAP.

The rest of the paper is organized as follows. We will first review relevant literature and then discuss the motivation and research methodology, followed by data analysis and the results. Conclusions and suggestions for future research are in the final section of this paper.

\section{LITERATURE REVIEW}

U.S. securities exchanges play a dominant role in equity share price discovery of ADR firms and the volume of shares traded on the home country exchange. There is comparatively sparse literature regarding price discovery for internationally cross-listed firms and the evidence addressing precisely in which domain cross-market price discovery occurs is mixed. The SEC Form 20-F filing and accompanying reconciliation to U.S. GAAP disclosures are arguably the most important source of reliable firm-specific information conveying new information beyond what is reported in accordance with home country accounting principles. Numerous investors seeking to earn rents from the incremental disclosures accompanying non-U.S. firms listing shares on U.S. exchanges drives the competitive market processes which arbitrage away such profits as an integral part of price formation processes.

Preparation of Form 20-F often involves a significant cost to firm management that elects to provide additional information required by the SEC filings. Form 20-F tends to increase investor confidence that stock transactions occur at prices formed based upon a broad and rich set of publically available information (Bailey et al., 2006). On the other hand, the SEC Form 20-F reconciling differences with U.S. GAAP earnings and equity impose important constraints on management accounting policy choices. The constraint arises as a result of the need to minimize the reconciling differences with U.S. GAAP in communicating the relative success of their prospective investment projects in order for investors to perceive the ADR as maintaining high-quality reporting practices. Quite naturally, more pronounced differences with U.S. GAAP earnings and equity raise important questions regarding earnings management practices (Chen \& Sami, 2013; Leuz, 2006).

We appeal to analytical research results reported in a considerable body of theoretical literature regarding the impact of costly voluntary management disclosures upon the equity share price formation process as the foundation of this research. Specifically, we make use of results reported by Fishman and Hagerty (1989) in which firms undertake costly voluntary disclosure and investors bear a cost of acquiring and interpreting the supplemental management disclosures. This improves the informativeness of share prices vis-a-vis future cash flows and resource allocation efficiency. The relevant literature indicates that information environments which are supportive of market price formation processes result in equity share prices which are informative about future events (Plumlee \& Plumlee, 2007). U.S.-listed ADR management's commitment to an increased level of disclosure for U.S. crosslisting can have the effect of increasing the incentives for informed market participants to collect and trade on private information, and, as a result, improve a U.S. listed ADR's information environment and stock price formation process. This intuition suggests that a U.S.-listed ADR's home information environment may be augmented by the additional disclosures which firm management commits to as a result of exchange required compliance with SEC regulations and U.S. GAAP. To date, however, there is limited direct evidence on the feedback relation between a U.S. listed ADR's disclosures and the equity information environment.

In 2007, the Final Rule No.33-8879 of the SEC eliminated the Form 20-F reconciliation to U.S. GAAP requirement for foreign firms presenting their financial statements in accordance with the English language version of International Financial Reporting Standards (IFRS) with their periodic filings. The SEC considers the additional opportunities for international diversification investment risk reduction, as a result, making listing on U.S. stock 
exchanges more attractive to non U.S. firms by reducing the costs associated with Form 20-F reconciliation requirement. However, the nature and magnitude of the related costs and benefits to both investors in U.S. securities markets and non U.S firms seeking access to U.S equity markets remain unsatisfactorily answered questions. Furthermore, broader policy related questions regarding the manner in which the costs and benefits associated with discontinuance of the Form 20-F reconciliation ought to be balanced between the interests of U.S. investors and those of non U.S. firms seeking access to U.S. securities markets, remain in need of further discussion and debate. For example, the extant literature provides no conclusive evidence regarding (1) the increased information costs arising from discontinuing the Form 20-F reconciliation for IASB IFRS foreign private issuers or (2) the additional international diversification benefits becoming available to U.S. investors as a result of increased numbers of non U.S. firms listing on U.S. stock exchanges subsequent to discontinuing the Form 20-F reconciliation requirement. Furthermore, the existing research literature provides little evidence regarding the nature and magnitude of the costs borne by non U.S. firms in complying with the Form 20-F reconciliation or the benefits accruing to non U.S. firms as a result of having increased (less costly) access to U.S. securities markets.

The literature addressing the statistical properties of accounting financial statement amounts generated using IAS/IFRS largely indicates that IFRS accounting principles generates accounting measures which are of higher quality in relation to home country accounting principles with the exception of U.S. GAAP. Barth, Landsman, and Lang (2008) use a sample of 319 IFRS reporting companies from 1990 to 2003 providing empirical results that indicates companies using IFRS display: (1) smaller degree of earnings smoothing, (2) loss recognition with greater timeliness, and (3) greater value relevance than firms applying non-US domestic GAAP. Results reported by Ashbaugh and Pincus (2001) indicate that analyst forecast errors for IFRS firms are smaller than firms using non U.S. domestic GAAP. On the other hand, Barth, Landsman, Lang, and Williams (2006) find that IAS/IFRS firms exhibit more earnings smoothing, more timely loss recognition, and less pronounced relation between accounting earnings and share prices in comparing IFRS to U.S. GAAP firms with a sample of 428 IFRS reporters from 1990 through 2004. They also find similar financial reporting quality for IFRS and U.S. GAAP measures using the subsample of firms that are cross-listed on U.S. stock exchanges.

The International Accounting literature examines the comparative information content of accounting numbers generated using alternative accounting principles before the advent of the EU 2005 wide-scale implementation of IFRS. An increasingly sizable body of related literature examines Form 20-F Item 17 or 18 reconciliations from non-US to U.S. GAAP establishing a solid historical foundation for interpretation of the value relevance of the Form 20-F reconciliations. In reviewing the extant research literature, Pownall and Schipper (1999) note that prior research documents significant differences between U.S. GAAP and both non-US GAAPs and IFRS using Form 20-F reconciliation data and provides some indication that the differences are value-relevant. Amir, Harris, and Venuti (1993), for example, examine the value relevance of Form 20-F reconciling items between non U.S. domestic and U.S. GAAP earnings and shareholders' equity 1981-1991 using a sample of 101 cross-listed companies. Their research results indicate that Form 20-F reconciliations are both in aggregate and for certain specific components (e.g., property revaluations and capitalized goodwill) equity share value relevant. Providing only inconclusive evidence regarding the equity share value relevance of the Form 20-F reconciliations, Harris and Muller (1999) investigate reconciliations of IFRS with U.S. GAAP for 31 companies from 1992 to 1996 and report: (1) U.S. GAAP earnings Form 20-F reconciliation is value relevant and (2) U.S. GAAP is more highly associated with market variables after controlling for IFRS amounts in specific empirical statistical models. Lang, Raedy, and Wilson (2006) compare 131 U.S. cross-listed Form 20-F foreign private Level II or Level III ADR issuers firms with U.S. companies over the years 1991-2002. Their results indicate that U.S. GAAP accounting principles measures for cross-listed firms differ from those of U.S. firms with respect to the time-series properties of reported earnings and accrual amounts, as well as the extent of the relation between accounting measures and equity share values. All things considered, the literature indicates that differences in the reporting of U.S. cross-listed companies and U.S. companies exist even with the reconciliations. Empirical evidence from this literature suggests that crosslisted firms engage in less earnings management than non-cross-listed firms.

\section{RESEARCH METHODOLOGY}

The sample for our research study is non-U.S. firms having ADRs listed on a major U.S. stock exchange and subject to the U.S. Securities and Exchange Commission periodic filing requirements. We merge lists of ADR 
companies from Bank of New York and JP Morgan ADR Universe websites to collect our sample for a period of 2000-2010. The final sample results in 402 ADR firms reporting to the SEC using Home Country Accounting Principles, IFRS, and U.S. GAAP. We examine the accounting policy footnote for each Form 20-F filed with the SEC during this time period in order to determine the accounting principles used to prepare the annual report included with the SEC Form 20-F filing.

The definitions of the variables employed in the statistical estimation and hypothesis tests and their computational measurement are listed and discussed below.

Definition of U.S. Exchange Listed ADR Form 20-F Accounting Principles Choice Market Variables Employed in Comparative Statistical Analyses of Cross Market Response to SEC Form 20-F Release

\begin{tabular}{|c|c|}
\hline Variable Abbreviation & Variable Definition and Computational Measurement \\
\hline \multicolumn{2}{|c|}{ 1. Annual Form 20-F Securities and Exchange Commission Filing } \\
\hline $\begin{array}{l}\text { Accounting Principles } \\
\text { Choice Variable SEC 20-F } \\
\text { GAAP }_{\text {it }}\end{array}$ & $\begin{array}{l}\text { Identification of whether U.S.-listed ADRs use U.S. GAAP, IFRS (or predecessors), or Home } \\
\text { Country Accounting Standards in filing annual Form 20-F with the U.S. Securities and } \\
\text { Exchange Commission. The determination of the accounting principles used for the SEC Form } \\
\text { 20-F Filing was obtained through examination of Form } 20-\mathrm{F} \text { on SEC EDGAR database } \\
\text { (SEC.gov). To indicate increasing quality of accounting disclosures, the qualitative variable } \\
\text { SEC 20-F GAAP } \text { it }_{\text {takes integer values } 1,2,3 \text {. }}\end{array}$ \\
\hline \multicolumn{2}{|c|}{ 2. Daily ADR and Equity Share Returns and ADR and Equity Share Market Returns } \\
\hline $\begin{array}{l}\text { U.S. Exchange Listed } \\
\text { ADR Share Return } R_{i t}\end{array}$ & $\begin{array}{l}\text { U.S. exchange-listed ADR share daily close price-to-close price dividend adjusted security } \\
\text { returns (i.e., } \mathrm{R}_{\mathrm{it}}=\frac{P_{i t}-P_{i t-1}+D_{i t}}{P_{i t-1}} \text { for } \mathrm{i}^{\text {th }} \mathrm{U} \text {.S. exchange-listed ADR sample firm on trading day } \\
\text { t). }\end{array}$ \\
\hline $\begin{array}{l}\text { Home Country Equity } \\
\text { Share Return LR }\end{array}$ & $\begin{array}{l}\text { U.S. exchange-listed ADR local ("L") market daily close price-to-close price dividend adjusted } \\
\text { security returns (i.e., } L R_{\mathrm{it}}=\frac{L P_{i t}-L P_{i t-1}+L D_{i t}}{L P_{i t-1}} \text { for } \mathrm{i}^{\text {th }} \mathrm{U} . \mathrm{S} \text {. exchange-listed ADR sample firm on } \\
\text { trading day t). }\end{array}$ \\
\hline $\begin{array}{l}\text { U.S. Exchange Listed } \\
\text { ADR Share Market Return } \\
\mathrm{R}_{\mathrm{mt}}\end{array}$ & $\begin{array}{l}\text { Equal weighted average daily close price-t } \\
\text { all firms (having non-missing data) and o } \\
\text { NYSE, AMEX, NASDAQ) from } 2000 \text { to } 20\end{array}$ \\
\hline 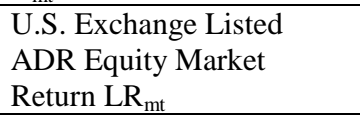 & $\begin{array}{l}\text { Equal weighted average daily close price-to-close price dividend-adjusted security return over } \\
\text { all firms (having non-missing data) and over all firms comprising the major local market index } \\
\text { for each sample firm local market. }\end{array}$ \\
\hline \multicolumn{2}{|c|}{ 3. Daily ADR and Equity Share Trading Volume and ADR and Equity Share Market Trading Volume } \\
\hline $\begin{array}{l}\text { U.S. Exchange Listed } \\
\text { ADR Share Trading } \\
\text { VolumeV }_{\text {it }}\end{array}$ & $\begin{array}{l}\text { U.S. exchange-listed (i.e., NYSE, AMEX, NASDAQ) ADR share daily number-of-shares } \\
\text { traded (i.e., } \mathrm{V}_{\text {it }}=\left[\frac{\text { Trading Volume }_{\text {it }}}{\text { Number of Shares Outstanding }}\right] \text { for } \mathrm{i}^{\text {th }} \mathrm{U} . \mathrm{S} \text {. exchange-listed ADR sample firm } \\
\text { on trading day t). }\end{array}$ \\
\hline $\begin{array}{l}\text { Home Country Equity } \\
\text { Share Return LV }\end{array}$ & $\begin{array}{l}\text { U.S. exchange-listed ADR local ("L") market daily number-of-shares traded (i.e., } \mathrm{LV}_{\mathrm{it}}= \\
{\left[\frac{\text { Local Trading Volume }}{\text { Local Shares Outstanding }_{\text {it }}}\right] \text { for } \mathrm{i}^{\text {th }} \text { U.S. exchange-listed ADR sample firm on trading day } \mathrm{t} \text { ). }}\end{array}$ \\
\hline $\begin{array}{l}\text { U.S. Exchange Listed } \\
\text { ADR Share Market Return } \\
\mathrm{V}_{\mathrm{mt}}\end{array}$ & $\begin{array}{l}\text { Equal weighted average daily number-of-shares traded over all firms (having non-missing data) } \\
\text { and over the three major exchanges trading ADRs (i.e., NYSE, AMEX, NASDAQ) from } 2000 \\
\text { to } 2010 \text {. }\end{array}$ \\
\hline $\begin{array}{l}\text { U.S. Exchange Listed } \\
\text { ADR Equity Market } \\
\text { Return } \mathrm{LV}_{\mathrm{mt}}\end{array}$ & $\begin{array}{l}\text { Equal weighted average daily number-of-shares traded over all firms (having non-missing data) } \\
\text { and over all firms comprising the major local market index for each sample firm local market. }\end{array}$ \\
\hline \multicolumn{2}{|c|}{ 4. Daily ADR Home Country to U.S. Dollar Exchange Rate } \\
\hline $\begin{array}{l}\text { Daily Percentage Change } \\
\text { In Home Country } \\
\text { Exchange Rate } \% \Delta \mathrm{ER}_{i t}\end{array}$ & $\begin{array}{l}\text { Percentage change in the daily spot home currency to U.S. dollar exchange rate (i.e., } \% \Delta E R_{i t}= \\
\left.\left[\frac{E R_{i t}-E R_{i t-1}}{E R_{i t-1}}\right]\right) \text {. }\end{array}$ \\
\hline
\end{tabular}

Descriptive statistics for the quantitative data variables employed in the statistical models and hypothesis tests are shown in Table 1 and Table 2. Table 1 shows distributional statistics for the data employed in the empirical analyses and Table 2 shows the Pearson and Spearman Rank correlation coefficients (and probability values for the test of the null hypothesis that the respective correlation coefficient is equal to zero) for the quantitative data variables used in this research. 
Table 1: Descriptive Statistics U.S.-Listed ADR and Security Return and Trading Volume

\begin{tabular}{|c|c|c|c|c|c|c|c|c|c|}
\hline \multicolumn{10}{|c|}{ Descriptive Statistics } \\
\hline \multirow[t]{2}{*}{ Statistic } & \multirow{2}{*}{$\begin{array}{c}\begin{array}{c}\text { Exch. } \\
\text { Rate }\end{array} \\
\text { ER }_{\text {it }} \\
\end{array}$} & \multicolumn{4}{|c|}{ ADR and Equity ShareReturns } & \multicolumn{4}{|c|}{ ADR and Equity Share Trading Volume } \\
\hline & & $\mathbf{R}_{\text {it }}$ & $\mathbf{L R}_{\text {it }}$ & $\mathbf{R}_{\mathrm{mt}}$ & $\mathbf{L R}_{\mathrm{mt}}$ & $\mathbf{V}_{\text {it }}$ & $\mathbf{L V}_{\text {it }}$ & $\mathbf{V}_{\mathrm{mt}}$ & $\mathbf{L V} \mathbf{m t}_{\mathrm{mt}}$ \\
\hline Mean & 0.003908 & 0.019605 & 0.018814 & 0.008392 & 0.009919 & 0.00866 & 0.00109 & 0.007815 & 0.002691 \\
\hline Std. Dev. & 0.005766 & 0250 & & 21 & & & & & 622 \\
\hline Median & 0.002022 & 0.012444 & $1.17 \mathrm{E}-02$ & 0.005431 & 0.0064 & 0.000611 & $9.00 \mathrm{E}-08$ & 0.007259 & 174 \\
\hline Kurtosis & & & & & & & & & \\
\hline Skewness & 7.409199 & 4.88971 & 5.80088 & 3.205792 & 3.317275 & 4.254238 & 21.91075 & 0.486224 & 1.684746 \\
\hline \multicolumn{10}{|c|}{$\begin{array}{l}\text { Variable Acronym Definitions: } R_{i t}: \text { U.S. exchange-listed ADR share daily close price-to-close price dividend adjusted security returns. } L R_{i t}: \text { U.S. } \\
\text { exchange-listed ADR local ("L") market daily close price-to-close price dividend adjusted security returns. } R_{m t}: \text { Equal-weighted average daily } \\
\text { close price-to-close price dividend-adjusted security return over all firms and over the three major exchanges trading ADRs. } L R_{m} t: \text { Equal } \\
\text { weighted average daily close price-to-close price dividend-adjusted security return over all firms and firms comprising the major local market } \\
\text { index for each sample firm. } V_{i t}: \text { U.S. exchange-listed ADR share daily number-of-shares traded. } L V_{i t}: \text { U.S. exchange-listed ADR local ("L") } \\
\text { market daily number-of-shares traded. } V_{m t}: \text { Equal weighted average daily number-of-shares traded over all firms and over the three major } \\
\text { exchanges trading ADRs. } L V_{m t}: \text { Equal weighted average daily number-of-shares traded over all firms and over all firms comprising the major } \\
\text { local market index for each sample firm local market. } \% \Delta E R_{i t}: \text { Percentage change in the daily spot home currency to U.S. dollar exchange rate. }\end{array}$} \\
\hline
\end{tabular}

Table 2: Pearson and Spearman Rank Correlation Coefficients Displaying Relationships Among U.S.-Listed ADR and Equity Share Returns and Trading Volume and U.S. Dollar Exchange Rates

\begin{tabular}{|c|c|c|c|c|c|c|c|c|c|c|c|}
\hline \multicolumn{12}{|c|}{ earson Correlation Coefficients: Prob $>|\rho|$ under $\mathbf{H}_{0}: \rho=0$} \\
\hline & \multicolumn{5}{|c|}{ ADR and Equity Share Returns and Exch. Rate } & & \multicolumn{5}{|c|}{ ADR and Equity Share Volume and Exch. Rate } \\
\hline & $\mathbf{R}_{\text {it }}$ & $\mathbf{L R}_{\text {it }}$ & $\mathbf{R}_{\mathrm{mt}}$ & $\mathbf{L R}_{\mathrm{mt}}$ & $\mathbf{E R}_{\text {it }}$ & & $\mathbf{V}_{\text {it }}$ & $L V_{\text {it }}$ & $\mathbf{V}_{\mathrm{mt}}$ & $\mathbf{L V} \mathbf{V}_{\mathrm{mt}}$ & $\mathbf{E R}_{\text {it }}$ \\
\hline & 1.00000 & 0.62311 & 0.36945 & 0.26268 & 0.13672 & & 1.00000 & 0.01479 & 0.11010 & 0.05040 & -0.01129 \\
\hline $\mathbf{R}_{\text {it }}$ & NA & $(<.0001)$ & $(<.0001)$ & $(<.0001)$ & $(<.0001)$ & $\mathbf{V}_{\text {it }}$ & NA & $(<.0001)$ & $(<.0001)$ & $(<.0001)$ & $(<.0001)$ \\
\hline & 0.62311 & 1.00000 & 0.23122 & 0.31162 & 0.12483 & & 0.01479 & 1.00000 & -0.04106 & 0.01705 & -0.01242 \\
\hline $\mathbf{L R}_{\text {it }}$ & $(<.0001)$ & NA & $(<.0001)$ & $(<.0001)$ & $(<.0001)$ & $L V_{\text {it }}$ & $(<.0001)$ & NA & $(<.0001)$ & $(<.0001)$ & $(<.0001)$ \\
\hline $\mathbf{R}_{1}$ & 0.36945 & 0.23122 & 1.00000 & 0.36897 & 0.19723 & $\mathbf{V}$ & 0.11010 & -0.04106 & 1.00000 & 0.18532 & 0.09781 \\
\hline $\mathbf{n}_{\mathrm{mt}}$ & $(<.0001)$ & $(<.0001)$ & NA & $(<.0001)$ & $(<.0001)$ & $\nabla_{m t}$ & $(<.0001)$ & $(<.0001)$ & NA & $(<.0001)$ & $(<.0001)$ \\
\hline $\mathbf{L} \mathbf{R}_{\mathrm{mt}}$ & 0.26268 & 0.31162 & 0.36897 & 1.00000 & 0.17038 & $\mathbf{L V}_{-}$ & 0.05040 & 0.01705 & 0.18532 & 1.00000 & -0.08557 \\
\hline $\mathbf{L K}_{\mathrm{mt}}$ & $(<.0001)$ & $(<.0001)$ & $(<.0001)$ & NA & $(<.0001)$ & $\mathbf{L} \mathbf{V m t}_{\mathrm{m}}$ & $(<.0001)$ & $(<.0001)$ & $(<.0001)$ & NA & $(<.0001)$ \\
\hline & 0.13672 & 0.12483 & 0.19723 & 0.17038 & 1.00000 & & -0.01129 & -0.01242 & 0.09781 & -0.08557 & 1.00000 \\
\hline $\mathbf{E} \mathbf{R}_{\text {it }}$ & $(<.0001)$ & $(<.0001)$ & $(<.0001)$ & $(<.0001)$ & NA & $\mathbf{E} \mathbf{R}_{\text {it }}$ & $(<.0001)$ & $(<.0001)$ & $(<.0001)$ & $(<.0001)$ & NA \\
\hline \multicolumn{12}{|c|}{ Spearman Rank Correlation Coefficients: Prob $>|\rho|$ under $\mathbf{H}_{0}: \rho=0$} \\
\hline & \multicolumn{5}{|c|}{ ADR and Equity Share Returns and Exch. Rate } & & \multicolumn{5}{|c|}{ ADR and Equity Share Volume and Exch. Rate } \\
\hline & $\mathbf{R}_{\text {it }}$ & $\mathbf{L R}_{\mathrm{it}}$ & $\mathbf{R}_{\mathrm{mt}}$ & $\mathbf{L R}_{\mathrm{mt}}$ & $\mathbf{E R}_{\text {it }}$ & & $\mathbf{V}_{\text {it }}$ & $L V_{\text {it }}$ & $\mathbf{V}_{\mathrm{mt}}$ & $\mathbf{L V} \mathbf{V}_{\mathrm{mt}}$ & $\mathbf{E R}_{\text {it }}$ \\
\hline & 1.00000 & 0.52606 & 0.31389 & 0.18735 & 0.05215 & & 1.00000 & 0.08779 & 0.17723 & 0.04664 & 0.07427 \\
\hline $\mathbf{K}_{\text {it }}$ & NA & $(<.0001)$ & $(<.0001)$ & $(<.0001)$ & $(<.0001)$ & $\mathbf{v}_{\text {it }}$ & NA & $(<.0001)$ & $(<.0001)$ & & $(<.0001)$ \\
\hline J & 0.52606 & 1.00000 & 0.18107 & 0.26540 & 0.07909 & & 0.08779 & 1.00000 & -0.52688 & 0.07739 & 0.10529 \\
\hline$L_{\text {it }}$ & $(<.0001)$ & NA & $(<.0001)$ & $(<.0001)$ & $(<.0001)$ & & $(<.0001)$ & NA & $(<.0001)$ & $(<.0001)$ & $(<.0001)$ \\
\hline $\mathbf{R}_{m p}$ & 0.31389 & 0.18107 & 1.00000 & 0.21250 & 0.07026 & & 0.17723 & -0.52688 & 1.00000 & 0.15844 & -0.01971 \\
\hline$K_{\mathrm{mt}}$ & $(<.0001)$ & $(<.0001)$ & NA & $(<.0001)$ & $(<.0001)$ & & $(<.0001)$ & & NA & & $(<.0001)$ \\
\hline $\mathbf{L} \mathbf{R}_{\mathrm{mt}}$ & 0.18735 & 0.26540 & 0.21250 & 1.00000 & 0.04605 & $\mathbf{L} \mathbf{V}_{m t}$ & 0.04664 & 0.07739 & 0.15844 & 1.00000 & -0.08227 \\
\hline & $(<.0001)$ & $(<.0001)$ & $(<.0001)$ & NA & $(<.0001)$ & $2 V_{m t}$ & $(<.0001)$ & $(<.0001)$ & $(<.0001)$ & NA & $(<.0001)$ \\
\hline $\mathbf{E R}_{\mathrm{it}}$ & 0.05215 & 0.07909 & 0.07026 & 0.04605 & 1.00000 & $\mathbf{E R}_{\text {it }}$ & 0.07427 & 0.10529 & -0.01971 & -0.08227 & 1.00000 \\
\hline & (<.0001) & (<.0001) & (<.0001) & $(<.0001)$ & & & $(<.0001)$ & $(<.0001)$ & (<.0001) & $(<.0001)$ & NA \\
\hline
\end{tabular}

\section{STATISTICAL MODEL AND HYPOTHESES}

The primary dependent variables of interest in this research are: (1) the U.S. ADR and equity share market returns coinciding with the SEC Form 20-F filing date and (2) the U.S. ADR and equity share market trading volume coinciding with the SEC Form 20-F filing date. Our fundamental research conjecture addresses whether a differential SEC Form 20-F ADR and equity share return and trading volume response manifests for the SEC Form 20-F GAAP choice for the U.S. ADR and home country equity shares. In order to investigate these relations, we utilize two equation simultaneous estimation approaches (i.e., Seemingly Unrelated Regression Equations and Telser (1964) approaches) to test statistical hypotheses regarding the similarity of the U.S. ADR and home country equity share returns and trading volume associated with the date of the SEC Form 20-F filing. Consequently, U.S. ADR and home country equity share return and trading volume are the two dependent variables and U.S. and home country market returns and trading volume are the independent variables. We use these return and trading volume models to estimate abnormal returns and trading volume associated with the SEC Form 20-F filing date for each of 
the SEC Form 20-F GAAP choices. The similarity of these magnitudes are the basis of the statistical hypotheses tests performed following upon the models employed.

\section{ADR and Equity Return Models}

The bivariate relation between U.S. ADR and home country equity returns underlying the first set of statistical tests is shown below. The statistical tests relating to Return Models No. 1 and No. 2 are shown in Research Propositions I-V and Null Hypotheses TestsReturns- $\mathrm{H}_{01-5}$ below. We employ (market factor) linear models of U.S. ADR and home country equity returns as dependent variables in order to control for U.S. and home country market wide movements in computing measures of U.S. ADR and home country equity unexpected returns.

\section{U.S. ADR Share Market Returns:}

Model No. $1 \quad \mathrm{R}_{\mathrm{it}}=\alpha_{0}+\alpha_{1} \mathrm{D}[\text { Local }]_{1}+\alpha_{2} \mathrm{D}[\mathrm{IFRS}]_{2}+\alpha_{3} \mathrm{D}[\mathrm{USGAAP}]_{3}+\alpha_{4} \mathrm{R}_{\mathrm{mt}}+\alpha_{5} \cdot \mathrm{ER}_{\mathrm{it}}+\mu_{\mathrm{it}}$

Local Market Equity Share Market Returns:

Model No. $2 \quad \mathrm{LR}_{\mathrm{it}}=\beta_{0}+\beta_{1} \cdot \mathrm{D}[\text { Local }]_{1}+\beta_{2} \mathrm{D}[\mathrm{IFRS}]_{2}+\beta_{3} \mathrm{D}[\mathrm{USGAAP}]_{3}+\beta_{4} \cdot \mathrm{LR}_{\mathrm{mt}}+\beta_{5} \cdot \mathrm{ER}_{\mathrm{it}}+v_{\mathrm{it}}$

After controlling for market wide movements, our fundamental research question involves whether unexpected returns occur in the ADR shares coinciding with the SEC $\beta$ Form 20-F filing date. Consequently, our first null hypothesis (Returns- $\mathrm{H}_{01}$ ) addresses whether the parameterized unexpected return regression coefficients $\alpha_{1}$, $\alpha_{2}$, and $\alpha 3$ take values which do not significantly differ from zero at the $\alpha=0.05$ confidence level as shown below. Our second null hypothesis (Returns- $\mathrm{H}_{02}$ ) addresses whether the parameterized unexpected return regression coefficients $\alpha_{1}, \alpha_{2}$, and $\alpha 3$ take values which do not significantly differ from one another as shown below.

\section{Returns: Fundamental Research Proposition I:}

Research Conjecture: We test the null hypothesis that values of SEC Form 20-F filing date ADR share unexpected returns are equal to zero for each of the three SEC Form 20-F GAAP Disclosure Quality Choices.

Null Hypothesis: Returns- $\mathrm{H}_{01}: \alpha_{1}=0 ; \alpha_{2}=0 ; \alpha_{3}=0$.

Returns: Fundamental Research Proposition II:

Research Conjecture: We test the null hypothesis that values of SEC Form 20-F filing date ADR share unexpected returns are equal to one another across all three of the three SEC Form 20-F GAAP Disclosure Quality Choices.

Null Hypothesis: Returns- $\mathrm{H}_{02}: \alpha_{1}=\alpha_{2}=\alpha_{3}$.

We hold similar interest in the local market equity share return response to the SEC Form 20-F GAAP Disclosure Quality Choices after controlling for home country market wide movements. Our fundamental research question involves whether unexpected returns occur in the home country local market equity shares coinciding with the SEC Form 20-F filing date. Consequently, our third null hypothesis $\left(\right.$ Returns- $\left.\mathrm{H}_{03}\right)$ addresses whether the parameterized unexpected equity share returns regression coefficients $\beta_{1}, \beta_{2}$, and $\beta 3$ take values which do not significantly differ from zero at the $\alpha=0.05$ confidence level as shown below. Our fourth null hypothesis (Returns $\mathrm{H}_{04}$ ) addresses whether the parameterized unexpected equity share returns regression coefficients $\beta_{1}, \beta_{2}$, and $\beta_{3}$ take values which do not significantly differ from one another at the $\alpha=0.05$ confidence level as shown below.

\section{Returns: Fundamental Research Proposition III:}

Research Conjecture: We test the null hypothesis that values of SEC Form 20-F filing date home country equity share unexpected returns are equal to zero for each of the three SEC Form 20-F GAAP Disclosure Quality Choices Levels.

Null Hypothesis: Returns- $\mathrm{H}_{03}: \beta_{1}=0 ; \beta_{2}=0 ; \beta_{3}=0$ at the $\alpha=0.05$ confidence level.

Returns: Fundamental Research Proposition IV:

Research Conjecture: We test the null hypothesis that values of SEC Form 20-F filing date home country equity share unexpected returns are equal to one another across all three of the three SEC Form 20-F GAAP Disclosure Quality Choice Levels. Null Hypothesis: Returns- $\mathrm{H}_{04}: \beta_{1}=\beta_{2}=\beta_{3}$. 
A second objective of this research is to examine the inter-market association between U.S. ADR share and home country equity share unexpected returns. For this reason, we test hypotheses regarding the equality of the of SEC Form 20-F filing date unexpected return response across the three SEC Form 20-F GAAP Disclosure Quality Choices i.e., $\alpha_{1}=\beta_{1}, \alpha_{2}=\beta_{2}$, and $\alpha_{3}=\beta_{3}$.

Returns: Fundamental Research Proposition V:

Research Conjecture: The inter-market magnitudes of SEC Form 20-F filing date U.S. ADR and home country equity share unexpected returns are similar across the three SEC Form 20-F GAAP Disclosure Quality Choice Levels.

Null Hypothesis: Returns- $\mathrm{H}_{05}: \alpha_{1}=\beta_{1}, \alpha_{2}=\beta_{2}$, and $\alpha_{3}=\beta_{3}$.

\section{ADR and Equity Trading Volume Models}

The bivariate relation between U.S. ADR and home country equity trading volume underlying the first set of statistical tests is shown below. The statistical tests relating to Volume Models No. 1 and No. 2 are shown in Research Propositions I-V and Null Hypotheses TestsVolume- $\mathrm{H}_{01-5}$ below.

Trading Volume Models: We employ (market factor) linear models of U.S. ADR and home country equity trading volume as dependent variables in order to control for U.S. and home country market wide movements in computing measures of U.S. ADR and home country equity unexpected trading volume.

U.S. ADR Share Market Trading Volume

Model No. 1: $\quad \mathrm{V}_{\mathrm{it}}=\alpha_{0}+\alpha_{1} \cdot \mathrm{D}[\text { Local }]_{\mathrm{it}}+\alpha_{2} \cdot \mathrm{D}[\mathrm{IFRS}]_{\mathrm{it}}+\alpha_{3} \mathrm{D}[\text { U.S. GAAP }]_{\mathrm{it}}+\alpha_{4} \cdot \mathrm{V}_{\mathrm{mt}}+\mu_{\mathrm{it}}$

Local Market Equity Share Market Trading Volume

Model No. 2: $\quad \mathrm{LV}_{\mathrm{it}}=\beta_{0}+\beta_{1} \cdot \mathrm{D}[\text { Local }]_{\mathrm{it}}+\beta_{2} \mathrm{D}[\mathrm{IFRS}]_{\mathrm{it}}+\beta_{3} \mathrm{D}[\mathrm{U} . \mathrm{S} \text {. GAAP }]_{\mathrm{it}}+\beta_{4} \cdot \mathrm{LV}_{\mathrm{mt}}+v_{\mathrm{it}}$

After controlling for market wide movements, our fundamental research question involves whether unexpected trading volume occurs in the ADR shares coinciding with the SEC Form 20-F filing date. Consequently, our first null hypothesis (Volume - $\mathrm{H}_{01}$ ) addresses whether the parameterized unexpected trading volume regression coefficients $\alpha_{1}, \alpha_{2}$, and $\alpha_{3}$ take values which do not significantly differ from zero at the $\alpha=0.05$ confidence level as shown below. Our second null hypothesis (Volume- $\mathrm{H}_{02}$ ) addresses whether the parameterized unexpected trading volume regression coefficients $\alpha_{1}, \alpha_{2}$, and $\alpha_{3}$ take values which do not significantly differ from one another at the $\alpha=$ 0.05 confidence level as shown below.

Volume: Fundamental Research Proposition I:

Research Conjecture: We test the null hypothesis that values of SEC Form 20-F filing date ADR share unexpected trading volume is equal to zero for each of the three SEC Form 20-F GAAP Disclosure Quality Choices.

Null Hypothesis: Volume $-\mathrm{H}_{01}: \alpha_{1}=0 ; \alpha_{2}=0$; and $\alpha_{3}=0$ at the $\alpha=0.05$ confidence level.

Volume: Fundamental Research Proposition II:

Research Conjecture: We test the null hypothesis that values of SEC Form 20-F filing date ADR share unexpected trading volume are equal to one another across all three of the three SEC Form 20-F GAAP Disclosure Quality Choices.

Null Hypothesis: Volume - $\mathrm{H}_{02}: \alpha_{1}=\alpha_{2}=\alpha_{3}$ at the $\alpha=0.05$ confidence level.

We hold similar interest in the local market equity shared trading volume response to the SEC Form 20-F GAAP Disclosure Quality Choices after controlling for home country market wide movements. Our fundamental research question involves whether unexpected trading volume occurs in the home country local market equity shares coinciding with the SEC Form 20-F filing date. Consequently, our third null hypothesis (Volume - $\mathrm{H}_{03}$ ) addresses whether the parameterized unexpected equity share trading volume regression coefficients $\beta_{1}, \beta_{2}$, and $\beta_{3}$ take values which do not significantly differ from zero at the $\alpha=0.05$ confidence level as shown below. Our fourth null hypothesis (Volume - $\mathrm{H}_{04}$ ) addresses whether the parameterized unexpected equity share trading volume regression coefficients $\beta_{1}, \beta_{2}$, and $\beta_{3}$ take values which do not significantly differ from one another at the $\alpha=0.05$ confidence level as shown below. 
Volume: Fundamental Research Proposition III:

Research Conjecture: We test the null hypothesis that values of SEC Form 20-F filing date home country equity share unexpected trading volume is equal to zero for each of the three SEC Form 20-F GAAP Disclosure Quality Choices Levels.

Null Hypothesis: Volume $-\mathrm{H}_{03}: \beta_{1}=0 ; \beta_{2}=0$; and $\beta_{3}=0$ at the $\alpha=0.05$ confidence level.

Volume: Fundamental Research Proposition IV:

Research Conjecture: We test the null hypothesis that values of SEC Form 20-F filing date home country equity share unexpected trading volume are equal to one another across all three of the three SEC Form 20-F GAAP Disclosure Quality Choice Levels.

Null Hypothesis: Volume $-\mathrm{H}_{04}: \beta_{1}=\beta_{2}=\beta_{3}$ at the $\alpha=0.05$ confidence level.

A second objective of this research is to examine the inter-market association between U.S. ADR share and home country equity share unexpected trading volume. For this reason, we test hypotheses regarding the equality of the SEC Form 20-F filing date unexpected trading volume response across the three SEC Form 20-F GAAP Disclosure Quality Choices i.e., $\alpha_{1}=\beta_{1}, \alpha_{2}=\beta_{2}$, and $\alpha_{3}=\beta_{3}$.

\section{Volume: Fundamental Research Proposition V:}

Research Conjecture: The magnitudes of SEC Form 20-F filing date U.S. ADR and home country equity share unexpected trading volume are similar across the three SEC Form 20-F GAAP Disclosure Quality Choice Levels.

Null Hypothesis: Volume $-\mathrm{H}_{05}: \alpha_{1}=\beta_{1}, \alpha_{2}=\beta_{2}$, and $\alpha_{3}=\beta_{3}$ at the $\alpha=0.05$ confidence level.

\section{Statistical Model Estimation and Results of Hypothesis Tests}

Table 3 shows the results of the ordinary least squares and SURE estimation of SEC Form 20-F filing date equity and ADR share abnormal returns and abnormal trading volume. Panel A of Table 3 shows that, in general, both equity and ADR shares accrue SEC Form 20-F filing date abnormal returns which are significantly different from zero at the $\alpha=0.05$ confidence level but which do not statistically differ from one another in magnitude (at the $\alpha=0.05$ confidence level). More specifically, ADR firms choosing to submit SEC Form 20-F using U.S. GAAP do not earn abnormal returns in the U.S. ADR market and ADR firms choosing to submit SEC Form 20-F using IFRS do not earn abnormal returns in the equity security market. Consequently, we conclude that U.S.-listed ADR firms accrue SEC Form 20-F filing date abnormal returns in both markets but which do not statistically differ from one another (at the $\alpha=0.05$ confidence level) over SEC Form 20-F GAAP Disclosure Quality Choice Levels. However, Panel B of Table 3 indicates that, generally speaking, the magnitude of SEC Form 20-F filing date abnormal returns for a given level of SEC Form 20-F GAAP Disclosure Quality Choice significantly differs between the U.S. ADR market and the equity home country market. That is to say, the magnitude of abnormal returns for Local Accounting Standards SEC Form 20-F GAAP Disclosure Quality Choice firms statistically differ between the ADR and equity security market at the $\alpha=0.05$ confidence. 
Table 3: Results of Cross-Market ADR and Equity Share Return Response to U.S.-Listed ADR SEC Form 20-F Accounting Principles Choice

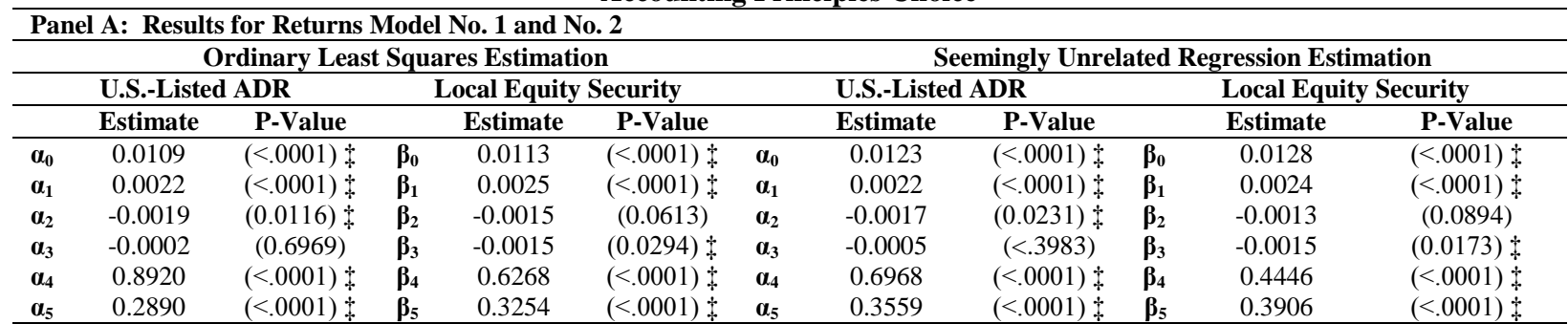

Single Equation Hypothesis Tests:

F-Test $\mathrm{H}_{0}: \alpha_{1}=\alpha_{2}=\alpha_{3}$

F-Statistic: $1.35(0.2603)$

F-Test $\mathrm{H}_{0}: \beta_{1}=\beta_{2}=\beta_{3}$

F-Test: $\alpha_{1}=\alpha_{2}=\alpha_{3}$

F-Statistic: $1.09(0.3367)$

F-Test: $\beta_{1}=\beta_{2}=\beta_{3}$

Panel B: Seemingly Unrelated Regression Estimation Cross-Equation Hypothesis Tests:

\begin{tabular}{|c|c|c|c|}
\hline Coefficient & Result & F-Stat & P-Val \\
\hline F-Test $\mathrm{H}_{0}: \alpha_{1}=\beta_{1}$ & Reject & 14.35 & $0.0001 \div$ \\
\hline F-Test $H_{0}: \alpha_{2}=\beta_{2}$ & Not Reject & 0.12 & 0.7290 \\
\hline F-Test $\mathrm{H}_{0}: \alpha_{3}=\beta_{3}$ & Not Reject & 0.30 & 0.5861 \\
\hline F-Test $H_{0}: \alpha_{1}+\alpha_{2}+\alpha_{3}=\beta_{1}+\beta_{2}+\beta_{3}$ & Not Reject & 2.93 & 0.0867 \\
\hline
\end{tabular}

F-Test $H_{0}: \alpha_{1}+\alpha_{2}+\alpha_{3}=\beta_{1}+\beta_{2}+\beta_{3}$

Panel C: Results for Trading Volume Model No. 1 and No. 2

\begin{tabular}{|c|c|c|c|c|c|c|c|c|c|c|c|}
\hline \multicolumn{7}{|c|}{ Ordinary Least Squares Estimation } & \multicolumn{5}{|c|}{ Seemingly Unrelated Regression Estimation } \\
\hline & \multicolumn{2}{|c|}{ U.S.-Listed ADR } & \multicolumn{3}{|c|}{ Local Equity Security } & & \multicolumn{2}{|c|}{ U.S.-Listed ADR } & \multicolumn{3}{|c|}{ Local Equity Security } \\
\hline & Estimate & P-Value & & Estimate & P-Value & & Estimate & P-Value & & Estimate & P-Value \\
\hline $\boldsymbol{\alpha}_{0}$ & 0.007062 & $(<.0001) \ddagger$ & $\boldsymbol{\beta}_{0}$ & 0.001081 & $(<.0001) \dagger$ & $\boldsymbol{\alpha}_{0}$ & 0.007038 & $(<.0001) \ddagger$ & $\boldsymbol{\beta}_{0}$ & 0.001086 & $(<.0001) \dagger$ \\
\hline$\alpha_{1}$ & 0.003603 & $(0.0034) \div$ & $\beta_{1}$ & -0.00085 & $(0.0189) \ddagger$ & $\alpha_{1}$ & 0.003602 & $(0.0034) \div$ & $\beta_{1}$ & -0.00085 & $(0.0188) \ddagger$ \\
\hline $\boldsymbol{\alpha}_{2}$ & -0.00322 & $(0.0841)$ & $\boldsymbol{\beta}_{2}$ & 0.000442 & $(0.4205)$ & $\alpha_{2}$ & -0.00322 & $(0.0836)$ & $\boldsymbol{\beta}_{2}$ & 0.000445 & $(0.4174)$ \\
\hline $\boldsymbol{\alpha}_{3}$ & 0.004342 & $(0.0032) \div$ & $\beta_{3}$ & 0.000388 & $(0.3705)$ & $\alpha_{3}$ & 0.004344 & $(0.0032) \div$ & $\beta_{3}$ & 0.000387 & $(0.3716)$ \\
\hline$\alpha_{4}$ & 1.184785 & $(<.0001) t$ & $\boldsymbol{\beta}_{4}$ & 0.085297 & $(<.0001) \ddagger$ & $\boldsymbol{\alpha}_{4}$ & 1.187992 & $(<.0001) t$ & $\beta_{4}$ & 0.083209 & $(<.0001) \ddagger$ \\
\hline$\alpha_{5}$ & -0.49781 & $(<.0001) \div$ & $\beta_{5}$ & -0.02849 & $(<.0001) t$ & $\alpha_{5}$ & -0.49799 & $(<.0001) \div$ & $\beta_{5}$ & -0.02857 & $(<.0001) t$ \\
\hline
\end{tabular}

Single Equation Hypothesis Tests:

F-Test $H_{0}: \alpha_{1}=\alpha_{2}=\alpha_{3} \quad$ F-Test $H_{0}: \beta_{1}=\beta_{2}=\beta_{3}$

F-Statistic: 5.88 (0.0028)

F-Statistic: $3.26(0.0385)$

F-Test: $\mathrm{H}_{0}: \alpha_{1}=\alpha_{2}=\alpha_{3}$ F-Statistic: $5.91(0.0027)$

ion Hypothesis Tests:

\begin{tabular}{lccc} 
Panel D: Seemingly Unrelated Regression Estimation Cross-Equation Hypothesis Tests: & F-Stat \\
\hline & Coefficient & Result & P-Val \\
F-Test $H_{0}: \alpha_{1}=\beta_{1}$ & Reject & 12.11 \\
F-Test $H_{0}: \alpha_{2}=\beta_{2}$ & Not Reject & 3.58 \\
F-Test $H_{0}: \alpha_{3}=\beta_{3}$ & Not Reject & $6.0005 \ddagger$
\end{tabular}

The table reports regression parameter estimates, t-statistics (in parentheses) relating to the test of the null hypothesis that the regression coefficient is equal to zero from ordinary least squares estimation. $t$ : Indicates the coefficient is significantly different from zero at less than the $\alpha$ $=0.05$.

Panel $\mathrm{C}$ of Table 3shows that, in general, both equity and ADR shares exhibit SEC Form 20-F filing date abnormal trading volume which is significantly different from zero at the $\alpha=0.05$ confidence level and which does statistically differ from one another in magnitude (at the $\alpha=0.05$ confidence level) across SEC Form 20-F GAAP Disclosure Quality Choice. More specifically, ADR firms choosing to submit SEC Form 20-F using IFRS do not exhibit abnormal trading volume in the U.S. ADR market and ADR firms choosing to submit SEC Form 20-F using IFRS and U.S. GAAP do not exhibit abnormal trading volume in the equity security market. Consequently, we conclude that U.S.-listed ADR firms exhibit SEC Form 20-F filing date abnormal trading in both markets which does statistically differ from one another (at the $\alpha=0.05$ confidence level) over SEC Form 20-F GAAP Disclosure Quality Choice Levels. Furthermore, Panel D of Table 3 indicates that, generally speaking, the magnitude of SEC Form 20-F filing date abnormal trading volume for a given level of SEC Form 20-F GAAP Disclosure Quality Choice significantly differs between the U.S. ADR market and the equity home country market. That is to say, the magnitude of abnormal returns for Local Accounting Standards SEC Form 20-F GAAP Disclosure Quality Choice firms statistically differ between the ADR and equity security market at the $\alpha=0.05$ confidence. 


\section{CONCLUSIONS}

This study evaluates the ADR and equity share response to U.S.-listed ADR Form 20-F filing in a manner similar to Chen and Sami $(2009,2008)$ anticipating that the incremental Form 20-F disclosures will prompt ADR and equity security share responses. Unlike prior studies, however, because a prominent attribute of ADR firms is that they benefit from multiple-market trading, we investigate whether the Form 20-F filings prompt U.S. dominant cross-market information flows from the ADR share market back to the home country equity share market proportional to the incremental Form 20-F SEC filing information. The perceived higher quality accounting disclosures required by the U.S. Securities and Exchange Commission for Level II and III ADRs listed on the major U.S. exchanges (i.e., NYSE, AMEX, and NASDAQ) ought to prompt an equity share market response proportional to the new information and, consequently, one ought to observe the rapid erosion of any accompanying pricing differentials as a result. Our results indicate that the U.S. ADR market response to the SEC form $20 \mathrm{~F}$ filing dominates the home-country equity share response for U.S. GAAP filers. The U.S. ADR and home equity market responses are virtually identical for home country accounting standards and IFRS filers. One contribution of this study is a more focused study of cross-market information transfers by examining the ADR and equity security return and trading volume behavior surrounding the U.S. Securities and Exchange Commission Form 20-F filing date which is known to be a unique source of unsurpassed accounting disclosures providing new information vis-avis the equity share market for a number of U.S.-listed ADR firms. Furthermore, this research provides a more complete perspective of the local global (i.e., ADR and equity market) reaction to the Form 20-F filing for U.S. exchange-listed ADRs as well as the role of security returns and trading volume in cross-market information transfers analogous to Chen and Sami (2008) and Chen and Sami (2009).

\section{AUTHOR INFORMATION}

Dr. David L. Senteney received Ph.D. in Accountancy from the University of Illinois at Urbana-Champaign, and is a Certified Public Accountant. He specializes in Financial Accounting and Auditing issues. He is a prolific author on FASB and IASB financial accounting, particularly relating to risk assessment and equity valuation. He has taught graduate and undergraduate financial accounting and analysis for over twenty years. Dr. Senteney's teaching career has primarily oriented around graduate accounting programs emphasizing AACSB accreditation and 150 hour CPA examination requirements. He is full time faculty in the School of Accountancy at Ohio University. E-mail: senteney.ohio@ymail.com

Dr. Grace Gao earned her Ph.D. in Educational Research and Evaluation from Ohio University and has Master Degrees in Accounting and International Studies from Ohio University. Dr. Gao's teaching focuses on research methodology, statistical analysis, and measurement and evaluation. In addition to teaching, Dr. Gao consults in the areas of assessment, research design, applied statistics, and standard setting. Dr. Gao's research interests focus on applied statistics, quantitative research methods. and measurement analysis, particularly statistics education, statistical computer programs, differential item functioning (DIF), item response theory (IRT), test equating, and test adaptation. E-mail: husenteney@mix.wvu.edu

Professor Mohammad S. Bazaz received his Ph.D. in accounting from University of Oklahoma. He specializes in financial, managerial, and international accounting. He has taught various accounting courses at the undergraduate and graduate levels both in the US and overseas universities including in Austria, Canada, Malaysia, India, Kosovo, and Iran. Dr. Bazaz's research focus is accounting regulations, foreign currency translation, segmental reporting, and event studies. He has published numerous articles in several national and international accounting journals. Dr. Bazaz has consulting engagements with several firms including Chrysler Corporation. E-mail: mbazaz@csusb.edu (Corresponding author)

\section{REFERENCES}

1. Amir, E., Harris, T., \& Venuti, E. (1993). A comparison of the value-relevance of U.S. vs. non-U.S. GAAP accounting measures using Form 20-F reconciliations. Journal of Accounting Research, 31(Supplement), 230-264. 
2. Ashbaugh, H., \& Pincus, M. (2001). Domestic accounting standards, international accounting standards, and the predictability of earnings. Journal of Accounting Research, 39(3), 417-434.

3. Bae, K.-H., \& Karolyi, G. A. (1994). Good news, bad news and international spill-overs of stock return volatility between Japan and the U.S. Pacific-Basin Finance Journal, 2, 405-438.

4. Bailey, W., Karolyi, G. A., \& Salva, C. (2006). The economic consequences of increased disclosure: evidence from international cross-listings. Journal of Financial Economics, 80, 175-213.

5. Barth, M., Landsman, W., \& Lang, M. H. (2008). International accounting standards and accounting quality. Journal of Accounting Research, 46(June), 467-498.

6. Barth, M., Landsman, W., Lang, M. H., \& Williams, C. (2006). Accounting quality: International accounting standards and U.S. GAAP. (Working paper). University of North Carolina.

7. Chan, K., \& Hameed, A. (2006). Stock price synchronicity and analyst coverage in emerging markets. Journal of Financial Economics, 80, 115-147.

8. Chen, L., \& Sami, H. (2008). Trading volume reaction to the earnings reconciliation from IAS to U.S. GAAP. Contemporary Accounting Research, 25(1), 15-33.

9. $\quad$----------, (2009), Trading volume reaction to the earnings reconciliation from IFRS to U.S. GAAP: Further evidence. (Working paper). http://papers.ssrn.com/sol3/papers.cfm?abstract_id=1392931

10. -------------, (2013), The impact of firm characteristics on trading volume reaction to the earnings reconciliation from IFRS to U.S. GAAP. Contemporary Accounting Research, $30(7$ \& 8), 697-718.

11. Fishman, \& Hagerty, K. (1989), Disclosure decisions by firms and the competition for price efficiency. The Journal of Finance, XLIV(3), 633-646.

12. Harris, M., \& Muller, K. (1999). The market valuation of IAS versus U.S. GAAP accounting measures using form 20-F reconciliations. Journal of Accounting and Economics, 26(1-3), 285-312.

13. Kanas, A. (1998), Volatility spillovers across equity markets: European evidence. Applied Financial Economics, 8, 245-256.

14. King, M., \& Wadhwani, S. (1990). Transmission of volatility between stock markets. Review of Financial Studies, 3, 5-33.

15. Lang, M., Raedy, J., \& Wilson, W. (2006). Earnings quality and cross listing: Are reconciled earnings comparable to us earnings? Journal of Accounting and Economics, 42(1-2), 255-283.

16. Lang, M. H., Raedy, J., \& Yetman, M. (2006). How representative are firms that are cross-listed in the United States? An analysis of accounting quality. Journal of Accounting Research, 41(2), 363-386.

17. Leuz, C. (2006). Cross listing, bonding and firms' reporting incentives: A discussion of Lang, Raedy and Wilson. Journal of Accounting and Economics, 42(1-2), 285-299.

18. Ng., A. (2000). Volatility spillover effects from Japan and the U.S. to the Pacific-Basin. Journal of International Money and Finance, 19, 207-233.

19. Plumlee, M., \& Plumlee, D. (2007). 20-F filers and SEC proposed changes: Some evidence of a U.S. home GAAP preference. (Working paper). University of Utah.

20. Pownall, G., \& Schipper, K. (1999). Implications of accounting research for the SEC's consideration of International Accounting Standards for U.S. securities offerings. Accounting Horizons, 13(3), 259-280.

21. Stulz, R. (1999). Globalization, corporate finance, and the cost of capital. Journal of Applied Corporate Finance, 12(3), 8-25.

22. SEC Release No. 33-8818 (Proposed Rule: Acceptance From Foreign Private Issuers Of Financial Statements Prepared In Accordance With International Financial Reporting Standards Without Reconciliation To U.S. GAAP) (July 2,2007) (the "Proposing Release").

23. SEC Release No. 33-8879 (Final Rule: Acceptance From Foreign Private Issuers of Financial Statements Prepared In Accordance With International Financial Reporting Standards Without Reconciliation To U.S. GAAP) (December 21, 2007) (the "Adopting Release"), which is available at http://www.sec.gov/rules/final/2007/33-8879.pdf

24. Telser, L. G. (1964). Advertising and competition. Journal of Political Economy, 72, 537-62. 


\section{NOTES}

